\title{
Optimization of Process Variables Affecting Osmotic Dehydration of Green Chili in Sucrose Solution by Response Surface Methodology
}

\author{
M. R. Haque ${ }^{1, *}$, M. M. Hosain ${ }^{2}$, M. S. Awal ${ }^{3}$, M. M. Kamal ${ }^{2}$ \\ ${ }^{1}$ Department of Food Engineering and Technology, Hajee Mohammad Danesh Science and Technology University, \\ Dinajpur, Bangladesh \\ ${ }^{2}$ Department of Food Processing and Preservation, Hajee Mohammad Danesh Science and Technology University, \\ Dinajpur, Bangladesh \\ ${ }^{3}$ Department of Food Science and Nutrition, Hajee Mohammad Danesh Science and Technology University, Dinajpur, Bangladesh \\ *Corresponding author: fetraihan12@hstu.ac.bd
}

Received January 11, 2019; Revised March 08, 2019; Accepted April 05, 2019

\begin{abstract}
Response surface methodology was used to investigate the effect of solute concentration $\left(30-70^{\circ} \mathrm{B}\right)$, solution temperature $\left(40-60^{\circ} \mathrm{C}\right)$ and process time $(15-300 \mathrm{~min})$ on water loss, solid gain and water loss to solid gain ratio during osmotic dehydration of green chili. The face centered central composite design (FCCD) with three factors at three different levels was used for optimizing the process variables. The models developed for all responses were found significant at $95 \%$ confidence level. It was found that all variables at linear level have significant effect on water loss (WL), solid gain (SG) and WL/SG ratio. The optimized conditions were solute concentration of $30^{\circ} \mathrm{B}$, solution temperature of $40^{\circ} \mathrm{C}$ and time of $299.93 \mathrm{~min}$ in order to obtain $\mathrm{WL}$ of $18.66 \%$, SG of $5.78 \%$ and $\mathrm{WL} / \mathrm{SG}$ ratio of 2.73 .
\end{abstract}

Keywords: osmotic dehydration, green chili, optimization, response surface methodology

Cite This Article: M. R. Haque, M. M. Hosain, M. S. Awal, and M. M. Kamal, "Optimization of Process Variables Affecting Osmotic Dehydration of Green Chili in Sucrose Solution by Response Surface Methodology." American Journal of Food Science and Technology, vol. 7, no. 3 (2019): 79-85. doi: 10.12691/ajfst-7-3-2.

\section{Introduction}

Chili (Capsicum annum) is one of the spice crops which cultivated everywhere in Bangladesh. The demand of chili is very high both in green and mature stages. It is eaten as raw and cooked vegetables or sometimes used for preparing various food products like salsas, pizzas, salads, etc [1]. Moreover, it is also used as a spice and flavoring ingredient for the preparation of various food products in the food industries [2]. However, the shelf-life of green chili is very short due to its high moisture content which accelerates microbial activity and deteriorate quickly $[3,4]$. It is noted that around $20 \%$ of the world perishable crops are dried to increase their shelf-life [5]. Drying is one of the oldest food preservation methods by which water is removed from the food material resulted in slow down the rate of microbial growth [6]. Fruits and vegetables are usually dried by sun drying or hot air drying. Nonetheless, it is an energy-intensive process and overall quality of the dehydrated product is lost to some extent due to thermal degradation. Osmotic dehydration is considered as simple and inexpensive pretreatment method prior to drying of foods. Furthermore, it reduces energy consumption for further drying process and improves the quality of final food products $[7,8]$.
Osmotic dehydration (OD) is the process of partial removal of water by immersing foods, mostly fruits and vegetables, in hypertonic solutions of sugar or salt $[9,10]$. In this process, the driving force for water removal is the concentration gradient between the hypertonic solution and plant tissue. In addition to, the diffusion of water takes place through a semi-permeable cell membrane and continued until equilibrium is established [11]. The osmotic dehydration process has been widely used for the development of new products of fruits and vegetable. Hence, it slightly alters in the sensorial and nutritional properties of the fresh product [12]. Additionally, osmotic dehydration is the best process to obtain a product of low water activity with extended shelf life. Thus it results in the better product stability and prevention from microbial spoilage though the product is partially dehydrated $[13,14]$. The market demand for commodities in a fresh like state has received a lot of attention in recent years. Although, they require the design, simulation, and optimization for obtaining a dehydrated product of good quality $[8,15]$.

Optimization of various food processes including osmotic dehydration can be achieved through a statistical tool called response surface methodology (RSM). Response surface methodology is an empirical modeling approach usually using polynomials to understand the quantitative relationship between multiple input variables and responses [16]. Nevertheless, limited study was taken 
previously on the osmotic dehydration and optimization of green chili. Therefore, the purpose of the present study was to investigate the effect of process variables on $\mathrm{WL}$, SG and WL/SG ratio during OD of green chili slices and to found optimum OD conditions.

\section{Materials and Methods}

\subsection{Materials}

Fresh green chili were purchased from a local food store, and stored at $5^{\circ} \mathrm{C}$ and $>95 \%$ relative humidity until used. The samples were thoroughly washed with water to remove adhering soil and other debris. Then the moisture content of fresh green chili was determined by drying the samples in a vacuum oven at $70^{\circ} \mathrm{C}$ for $14-16 \mathrm{~h}$ [17]. The initial moisture content of green chili slices was $81.46 \pm 0.54 \%(\mathrm{wb})$.

\subsection{Preparation of Osmotic Solutions}

The osmotic solution $\left(30-70^{\circ} \mathrm{B}\right)$ was prepared by dissolving the required quantity of food grade sugar (Fresh refined sugar, United Sugar Mills Ltd., Narayanganj, Bangladesh) in distilled water $(\mathrm{w} / \mathrm{w})$. The total soluble solids $\left({ }^{\circ} \mathrm{B}\right)$ content of the solution was then measured using a digital Refractometer (model-HI96801).

\subsection{Experimental Design}

A face-centered central composite design (FCCD) with three variables at three levels was used as the experimental design given in Table 1. The FCCD design predicts uniformly at all constant distances from their centre points. The variables chosen for osmotic dehydration experiments were solution temperature (A), solute concentration (B) and process time (C). The variables and their levels were selected on the basis of previous literature $[6,12,18,19]$. These were the solution temperature in the range of $40-60^{\circ} \mathrm{C}$, solute concentration in the range $30-70^{\circ} \mathrm{B}$, and process time of $15-300 \mathrm{~min}$. The ratio of the sample (green chili) to the sucrose osmotic solution was kept constant at 1:3 by weight [20]. Agitation was performed for reducing the mass transfer resistance and for good mixing [21]. Table 2 indicates the combination of process variable levels used in the FCCD. The experiments were conducted randomly in order to minimize the effects of unexplained variability in the observed responses.

Table 1. Process variables and their levels of FCCD experimental design

\begin{tabular}{clccc}
\hline Symbol & Independent Variables & \multicolumn{3}{c}{ Range and levels } \\
\hline & & -1 & 0 & +1 \\
$\mathrm{~A}$ & Solution temperature, ${ }^{\circ} \mathrm{C}$ & 40 & 50 & 60 \\
$\mathrm{~B}$ & Solute concentration, ${ }^{\circ} \mathrm{B}(\mathrm{Brix})$ & 30 & 50 & 70 \\
$\mathrm{C}$ & Time, min & 15 & 157.5 & 300 \\
\hline
\end{tabular}

\subsection{Osmotic Dehydration of Green Chili}

For each experiment, green chili were cleaned, removed stalk and cut into small pieces of approximately $5 \pm 0.01$ $\mathrm{mm}$. During experimentation, known weights of green chili slices $(150 \mathrm{~g})$ were put in the glass beakers containing calculated volume of osmotic solutions of different concentrations. The beaker was covered with a sheet of aluminum film to prevent evaporation of osmotic solutions.

Table 2. Face centered central composite design with experimental values of response variables

\begin{tabular}{|c|c|c|c|c|c|c|c|}
\hline \multirow{2}{*}{ Run } & \multirow{2}{*}{ Type } & \multicolumn{3}{|c|}{ Uncoded process variables } & \multicolumn{3}{|c|}{ Responses } \\
\hline & & Solution temperature $\left({ }^{\circ} \mathrm{C}\right)$ & Solute concentration $\left({ }^{\circ}\right.$ Brix $)$ & Time (min) & Water loss $(\%)$ & Solid gain $(\%)$ & $\mathrm{WL} / \mathrm{SG}$ ratio \\
\hline 1 & Center & 50.0 & 50.0 & 157.50 & 22.91 & 18.54 & 1.23 \\
\hline 2 & Center & 50.0 & 50.0 & 157.50 & 24.76 & 21.75 & 1.13 \\
\hline 3 & Center & 50.0 & 50.0 & 157.50 & 24.33 & 19.86 & 1.22 \\
\hline 4 & Fact & 40.0 & 70.0 & 300.0 & 29.87 & 16.34 & 1.82 \\
\hline 6 & Fact & 40.0 & 70.0 & 15.0 & 8.05 & 5.13 & 1.56 \\
\hline 7 & Fact & 40.0 & 30.0 & 300.0 & 18.20 & 6.48 & 2.80 \\
\hline 8 & Axial & 60.0 & 50.0 & 157.50 & 24.68 & 16.62 & 1.48 \\
\hline 9 & Center & 50.0 & 50.0 & 157.50 & 24.43 & 18.6 & 1.31 \\
\hline 10 & Axial & 50.0 & 50.0 & 300.0 & 25.21 & 19.91 & 1.26 \\
\hline 12 & Fact & 60.0 & 70.0 & 15.0 & 17.74 & 10.08 & 1.76 \\
\hline 13 & Fact & 40.0 & 30.0 & 15.0 & 8.40 & 3.19 & 2.63 \\
\hline 14 & Fact & 60.0 & 30.0 & 15.0 & 10.09 & 3.71 & 2.72 \\
\hline 15 & Center & 50.0 & 50.0 & 157.50 & 22.66 & 18.95 & 1.19 \\
\hline 16 & Fact & 60.0 & 70.0 & 300.0 & 35.61 & 30.15 & 1.18 \\
\hline 17 & Axial & 50.0 & 70.0 & 157.50 & 26.06 & 21.09 & 1.23 \\
\hline 18 & Center & 50.0 & 50.0 & 157.50 & 21.87 & 18.94 & 1.15 \\
\hline 19 & Fact & 60.0 & 30.0 & 300.0 & 20.14 & 12.41 & 1.62 \\
\hline 20 & Axial & 40.0 & 50.0 & 157.50 & 19.75 & 10.95 & 1.80 \\
\hline
\end{tabular}


The temperature was controlled by a thermostatic water bath according to the experimental design during osmosis. Furthermore, for each experiment agitation speed was maintained constant at $70 \mathrm{rpm}$. At the predetermined times, the slices were removed from the osmotic solutions and rinsed quickly with water to remove surplus solvent adhering to the surfaces. The osmotically dehydrated samples were then spread on the tissue paper to remove the free water present on the surface. After that, about $20-25 \mathrm{~g}$ of sample was taken for determination of dry matter by oven drying method. The oven dried samples were cooled in desiccators containing silica gel for half an hour, packed in HDPE bags and kept at ambient temperature for further analysis. All experiments were done in duplicate and the average value was taken for computation.

\subsection{Measurement of Water Loss and Solid Gain}

The mass transfer parameters i.e. water loss (WL) and solid gain (SG) were calculated by the equations given by Panagiotou et al. [22]:

$$
\begin{gathered}
W L=\frac{\left(M_{o}-M\right)(M-S)}{M_{o}} \\
S G=\frac{S-S_{o}}{M_{o}}
\end{gathered}
$$

Where, $M_{o}$ is the initial mass of fresh sample $(\mathrm{g}), \mathrm{M}$ is the mass of sample $(\mathrm{g})$ after time $\mathrm{t}$ of osmotic treatment, $\mathrm{S}$ is the dry matter of sample ( $g$ ) after time $t$ of osmotic treatment and $\mathrm{S}_{\mathrm{o}}$ is the initial dry matter of sample $(\mathrm{g})$.

\subsection{Ratio of Moisture Loss over Solids Gain}

The efficiency of osmotic dehydration process can be described by the ratio of water loss (WL) and solid gain (SG) which was calculated by the following equation:

$$
\text { Ratio }=\frac{W L}{S G} .
$$

\subsection{Statistical Analysis and Optimization}

The following second-order polynomial (SOP) model was fitted to the experimental data of each dependent variable as given in below:

$$
Y_{k}=b_{k o}+\sum_{i=1}^{3} b_{k i} x_{i}^{2}+\sum_{i=1}^{2} \sum_{j=i=1}^{3} b_{k i j} x_{i} x_{j}+e_{k}
$$

where, $x$ is the coded independent variable and $b_{k 0}, b_{k i}, b_{k i i}$, and $b_{\text {kij }}$ are constant regression coefficients. The multiple regression analysis was conducted to investigate the main effects of various process parameters on the various responses. Modeling was started with a quadratic model in which linear, squared and interaction terms were also included. Two-way analysis of variance (ANOVA) was conducted for finding significant model terms for each response. Significant terms in the model was judged by determining the probability level that the F-statistic value calculated from the data is less than $5 \%$ [23]. The model adequacies were assessed by $\mathrm{R}^{2}$, adjusted- $\mathrm{R}^{2}$ and Predicted- $\mathrm{R}^{2}$. After model fitting, residual analysis was carried out to validate the assumptions used in the ANOVA (results are not shown). Desirability function method was performed for maximizing and minimizing of the polynomials thus fitted and mapping of the fitted responses was accomplished using Design Expert version 7.0 statistical software.

\section{Results and Discussion}

\subsection{Fitting Models}

The results of second-order response surface model in the form of analysis of variance (ANOVA) are given in Table 3. The regression analysis indicated that all the process variables were found to be statistically significant for water loss (WL), solid gain (SG) and WL/SG-ratio at $\mathrm{p}<0.05$. A model F-value of 64.38, 28.81 and 61.02 for $\mathrm{WL}, \mathrm{SG}$, and WL/SG-ratio implies respectively that the model is significant $(\mathrm{p}<0.05)$. The ANOVA also demonstrated that the lack of fit was not significant for all response surface models at $95 \%$ confidence level. However, $\mathrm{R}^{2}$, adjusted- $\mathrm{R}^{2}$ and predicted- $\mathrm{R}^{2}$ was computed to check the model adequacy. The coefficient of determination $\left(\mathrm{R}^{2}\right)$ measures the goodness of fit of the model. The high $\mathrm{R}^{2}(>0.95)$ was obtained for each response surface model which indicates that the models are highly compatible (Table 3). Furthermore, the adjusted- $\mathrm{R}^{2}$ was used to assess the model adequacy and should be over $90 \%$. The adjusted- $\mathrm{R}^{2}$ value was found to be $0.97,0.93$ and 0.96 for $\mathrm{WL}, \mathrm{SG}$, and WL/SG-ratio, respectively. The predicted- $\mathrm{R}^{2}$ evaluates the amount of variation in new data explained by the model and found in reasonable agreement with the adjusted- $\mathrm{R}^{2}$. The coefficient of variance $(\mathrm{CV})$ is defined as the relative dispersion of the experimental points from the predicted values of the SOP models [24]. The CV values were found to be $6.34 \%, 13.32 \%$ and $6.02 \%$ for $\mathrm{WL}, \mathrm{SG}$, and WL/SG-ratio, respectively. The developed models, in the form of coded independent process variables, are as follows:

$$
\begin{aligned}
\mathrm{WL}= & 22.90+2.40 \mathrm{~A}+4.25 \mathrm{~B}+7.56 \mathrm{C} \\
& +1.47 \mathrm{AB}-0.46 \mathrm{AC}+2.48 \mathrm{BC} \\
& +0.21 \mathrm{~A}^{2}+0.015 \mathrm{~B}^{2}-4.83 \mathrm{C}^{2} \\
\mathrm{SG}= & 18.38+3.09 \mathrm{~A}+4.69 \mathrm{~B}+5.68 \mathrm{C} \\
& +1.54 \mathrm{AB}+1.78 \mathrm{AC}+2.41 \mathrm{BC} \\
& -3.00 \mathrm{~A}^{2}-1.19 \mathrm{~B}^{2}-3.65 \mathrm{C}^{2} \\
\mathrm{WL} / \mathrm{SG}-\mathrm{ratio}= & 1.22-0.19 \mathrm{~A}-0.40 \mathrm{~B}-0.14 \mathrm{C} \\
& +0.081 \mathrm{AB}-0.26 \mathrm{AC}+0.075 \mathrm{BC} \\
& +0.41 \mathrm{~A}^{2}+0.27 \mathrm{~B}^{2}+0.12 \mathrm{C}^{2}
\end{aligned}
$$

Where, $\mathrm{WL}=$ water loss $(\%), \mathrm{SG}=$ solid gain $(\%)$, $\mathrm{A}=$ temperature $\left({ }^{\circ} \mathrm{C}\right), \quad \mathrm{B}=$ solute concentration $\left({ }^{\circ} \mathrm{B}\right)$, $\mathrm{C}=$ process time $(\mathrm{min})$. 
Table 3. Regression summary and ANOVA for WL, SG and WL/SG-ratio

\begin{tabular}{|c|c|c|c|c|c|c|c|c|c|c|c|c|c|}
\hline \multirow[t]{2}{*}{ Source } & \multirow[t]{2}{*}{ df } & \multicolumn{4}{|c|}{ Water loss } & \multicolumn{4}{|c|}{ Solid gain } & \multicolumn{4}{|c|}{$\mathrm{WL} / \mathrm{SG}$ ratio } \\
\hline & & $\beta$ & $\begin{array}{l}\text { Sum of } \\
\text { square }\end{array}$ & F- value & $p$-value & $\beta$ & $\begin{array}{l}\text { Sum of } \\
\text { square }\end{array}$ & F- value & $p$-value & $\beta$ & $\begin{array}{l}\text { Sum of } \\
\text { square }\end{array}$ & F-value & $p$-value \\
\hline Model & 9 & 22.90 & 989.08 & 64.38 & $0.0001^{\mathrm{S}}$ & 18.38 & 961.10 & 28.81 & $0.0001^{\mathrm{S}}$ & 1.22 & 5.22 & 61.02 & $0.0001^{\mathrm{S}}$ \\
\hline Temp (A) & 1 & 2.40 & 57.57 & 33.73 & $0.0002^{\mathrm{S}}$ & 3.09 & 95.39 & 25.73 & $0.0005^{\mathrm{s}}$ & -0.19 & 0.35 & 37.01 & $0.0001^{\mathrm{S}}$ \\
\hline $\begin{array}{c}\text { Solute } \\
\text { Conc.(B) }\end{array}$ & 1 & 4.25 & 180.77 & 105.90 & $0.0001^{\mathrm{S}}$ & 4.69 & 220.01 & 59.35 & $0.0001^{\mathrm{S}}$ & -0.40 & 1.59 & 167.55 & $0.0001^{\mathrm{S}}$ \\
\hline Time (C) & 1 & 7.56 & 571.90 & 335.02 & $0.0001^{\mathrm{S}}$ & 5.68 & 322.94 & 87.11 & $0.0001^{\mathrm{s}}$ & -0.14 & 0.20 & 20.95 & $0.0010^{\mathrm{S}}$ \\
\hline $\mathrm{AB}$ & 1 & 1.47 & 17.39 & 10.19 & $0.0096^{\mathrm{S}}$ & 1.54 & 18.92 & 5.10 & $0.0474^{\mathrm{S}}$ & 0.081 & 0.052 & 5.47 & $0.0414^{\mathrm{S}}$ \\
\hline $\mathrm{AC}$ & 1 & -0.46 & 1.71 & 1.0 & 0.3409 & 1.78 & 25.46 & 6.87 & $0.0256^{\mathrm{S}}$ & -0.26 & 0.56 & 58.51 & $0.0001^{\mathrm{S}}$ \\
\hline $\mathrm{BC}$ & 1 & 2.48 & 49.18 & 28.81 & $0.0003^{S}$ & 2.41 & 46.50 & 12.54 & $0.0053^{S}$ & 0.075 & 0.045 & 4.74 & 0.0545 \\
\hline $\mathrm{A}^{2}$ & 1 & 0.21 & 0.12 & 0.072 & 0.7945 & -3.0 & 24.72 & 6.67 & $0.0027^{\mathrm{s}}$ & 0.41 & 0.46 & 48.41 & $0.0001^{\mathrm{S}}$ \\
\hline $\mathrm{B}^{2}$ & 1 & 0.015 & $6.01 \mathrm{E}-04$ & $3.52 \mathrm{E}-04$ & 0.9854 & -1.19 & 3.87 & 1.04 & 0.3309 & 0.27 & 0.20 & 21.49 & $0.0009^{\mathrm{S}}$ \\
\hline $\mathrm{C}^{2}$ & 1 & -4.83 & 64.27 & 37.65 & $0.0001^{\mathrm{S}}$ & -3.65 & 36.74 & 9.91 & $0.0104^{\mathrm{S}}$ & 0.12 & 0.038 & 3.95 & 0.0748 \\
\hline Lack of fit & 5 & & 10.23 & 1.49 & $0.3350^{\mathrm{NS}}$ & & 29.55 & 3.93 & 0.0796 NS & & 0.075 & 3.76 & $0.0862^{\mathrm{NS}}$ \\
\hline $\mathrm{R}^{2}$ & & & 0.98 & & & & 0.96 & & & & 0.98 & & \\
\hline Adjusted $\mathrm{R}^{2}$ & & & 0.97 & & & & 0.93 & & & & 0.96 & & \\
\hline Predicted $\mathrm{R}^{2}$ & & & 0.90 & & & & 0.82 & & & & 0.81 & & \\
\hline C.V. \% & & & 6.34 & & & & 13.32 & & & & 6.02 & & \\
\hline
\end{tabular}

$\mathrm{S}=$ significant at $5 \%$ level of significance $(\mathrm{p}<0.05) ; \mathrm{NS}=$ nonsignificant at $5 \%$ level significance $(\mathrm{p}>0.05) ; \beta=\mathrm{Co}-\mathrm{efficient}$ of estimation.

\subsection{Influence of Process Variables on Water Loss (WL)}

Results of the statistical analysis for water loss (WL) are given in Table 3. All the process variables at linear level have significant effect on WL at 5\% level of significance. The magnitude of $\beta$ values indicates the maximum positive effect of process duration $(\beta=7.56)$ followed by solute concentration $(\beta=4.25)$ and osmotic solution temperature $(\beta=2.40)$ on water loss. It implies increased water loss with increase of process duration and solute concentration. Similar phenomenon for water loss was also reported in earlier studies by Mundada et al. [25] and Jain et al. [26] for pomegranate arils and papaya cubes, respectively. However, the quadratic terms of the process duration was also highly significant, whereas the quadratic terms of solute concentration and osmotic solution temperature were not significant.

Figure 1 (a) shows the increase of water loss with the increase on the osmotic solution concentration with time, which was more significant in high concentration than in low concentration. Furthermore, the rate of removal of water was more pronounced at the beginning of the osmotic dehydration process. This behavior is due to the increase in the osmotic pressure gradient between the concentrated solution and the fresh sample [27,28]. The water loss increased with the increase in osmotic solution temperature and solute concentration from 50 to $65^{\circ} \mathrm{B}$ (Figure 1(b)). The increase in water loss is higher at higher temperatures because of the rise on cell membrane permeability, promotes swelling and plasticization of the cell membrane thus favoring mass transfer $[29,30]$.
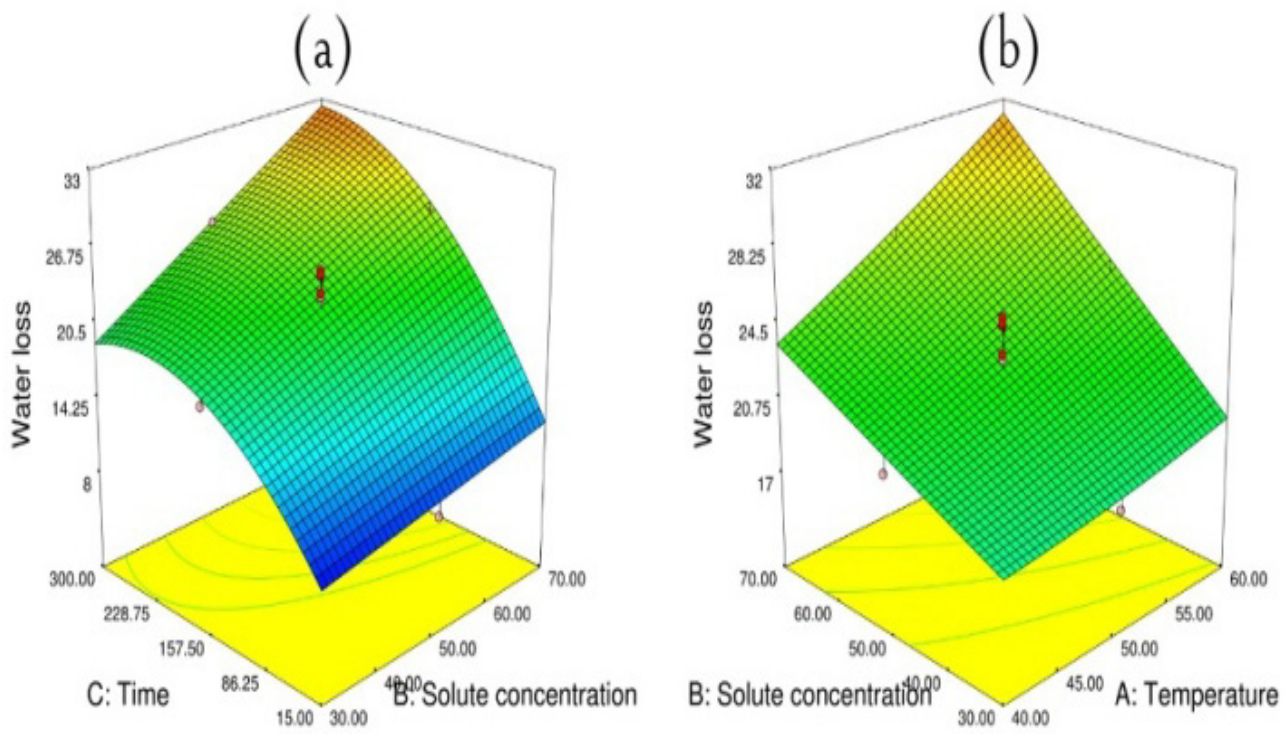

Figure 1. Response surface plots for water loss as a function of (a) solute concentration and process time (b) temperature and solute concentration 


\subsection{Influence of Process Variables on Solid Gain (SG)}

The $p$ value from Table 3 indicates that all linear terms of process variables have significant effect on solid gain at 95\% confidence level. Moreover, the quadratic terms of solution temperature and time have negative and significant effect on solid gain during osmotic dehydration of green chili $(p<0.05)$. The relative magnitude of $\beta$ values indicates the maximum contribution of process time $(\beta=5.68)$ followed by solute concentration $(\beta=4.69)$ and temperature $(\beta=3.09)$ on solid gain (Table 3$)$. These results indicate that an increased SG with increase of solution temperature, solute concentration and time. These results are in accordance with the findings of Ganjloo et al. [31] obtained during osmotic dehydration of seedless guava.

As shown in Figure 2 (a), the solid gain increased with combined increase in solute concentration and process time. Jokić et al. [32] reported similar findings of increasing solid gain with increase of immersion time and solute concentration during OD of sugar beet. Figure 2 (b) and 2 (c) indicated that SG increased significantly with increase in temperature, solute concentration, and contact time. This is because of increasing temperature induced a reduction on solution viscosity resulted in lowering external resistance to mass transfer. As a consequence, it makes water and solutes transfer easier through the tissue structure. Similar results were obtained by Khoyi and Hesari [33] and İspir and Toğrul [34] for OD of apricot.

\subsection{Influence of Process Variables on WL/SG Ratio}

The magnitude of $p$ and $\beta$ values in Table 3 indicates the maximum negative and significant contribution of solute concentration $(\beta=-0.4)$ followed by solution temperature $(\beta=-0.19)$, process time $(\beta=-0.14)$ on the $\mathrm{WL} / \mathrm{SG}$ ratio. It implies decrease in $\mathrm{WL} / \mathrm{SG}$ ratio with increase of temperature, solute concentration and time. The quadratic terms of solution temperature and solute concentration have the positive and significant effect while process duration has the non-significant effect on $\mathrm{WL} / \mathrm{SG}$ ratio. The positive coefficients of the quadratic terms suggested that an excessive increase in the levels of these variables resulted in significant increase in WL/SG ratio.
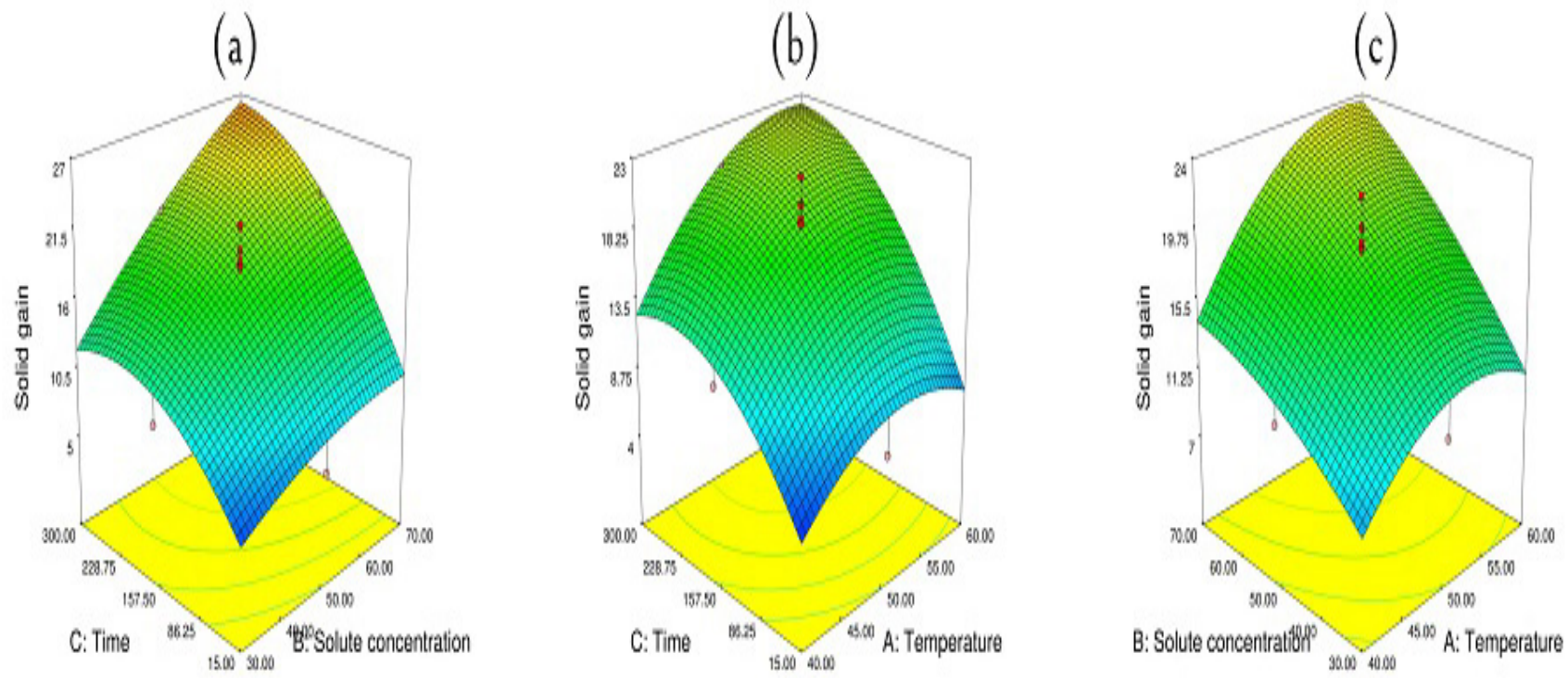

Figure 2. Response surface plots for solid gain as a function of (a) solute concentration and time (b) temperature and time (c) temperature and solute concentration

(a)

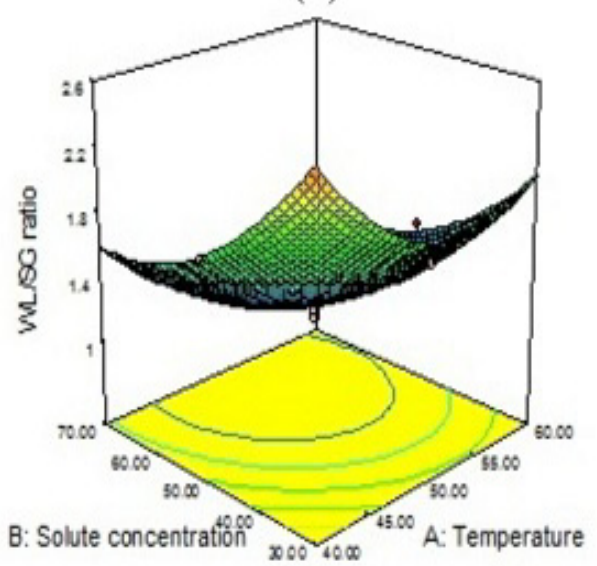

(b)

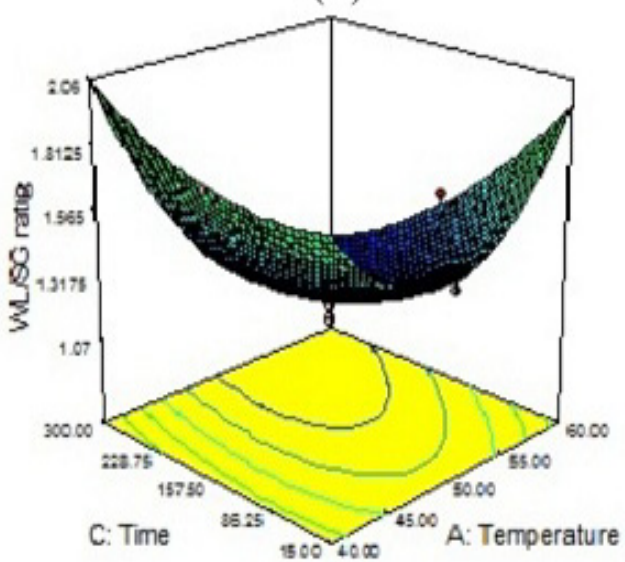

Figure 3. Response surface plots for WL/SG-ratio as a function of (a) temperature and solute concentration (b) temperature and process time. 
The WL/SG ratio showed an initial increasing trend with increase in osmotic solution temperature and solute concentration from 30 to $40^{\circ} \mathrm{B}$. However, when the solute concentration reached to a maximum level, the WL/SG ratio was declined gradually with increase in temperature (Figure 3(a)). Mandala et al. [6] also observed higher dehydration efficiency index (WL/SG) when the samples treated in $45 \%$ sucrose solution during OD of apple. The interaction of time and temperature showed a decreasing effect on the ratio of water loss to solid gain (Figure 3(b)). These results indicate an increase in WL/SG ratio with increase in process duration up to a level and after it decreased for a specific solution temperature.

\subsection{Optimization of the Osmotic Dehydration Process}

Numerical optimization of the osmotic dehydration process for green chili was performed using the desirability function methodology. The solution having maximum desirability value was selected as the optimum condition. In order to optimize the osmotic dehydration process the maximization of $\mathrm{WL}, \mathrm{WL} / \mathrm{SG}-$ ratio and minimization of SG were the considerations. The best solution was found with a desirability value of 0.69 at a solute concentration of $30^{\circ} \mathrm{B}$, solution temperature of $40^{\circ} \mathrm{C}$ and time of $299.93 \mathrm{~min}$. At these conditions, the maximum WL, WL/SG-ratio and minimum SG were obtained, showing predicted values of $18.66 \%, 2.73$ and $5.78 \%$, respectively. Furthermore, the predicted optimum conditions were experimentally validated with a slight modification in process time by $300 \mathrm{~min}$ in exchange of $299.93 \mathrm{~min}$. The results were found close to the estimated ones with error lower than $40 \%$, indicating that the statistical analysis was good enough.

\section{Conclusions}

The RSM was an effective tool in optimizing process variables for osmotic dehydration of green chili in sucrose solution having concentration in the range of $30-70^{\circ} \mathrm{B}$, temperature of $40-60^{\circ} \mathrm{C}$ and time of $15-300 \mathrm{~min}$. The results clearly demonstrated that the developed models were appropriate to be used for predicting WL, SG and WL/SG-ratio of green chili slices. The optimum processing conditions were found to be solute concentration of $30^{\circ} \mathrm{B}$, solution temperature of $40^{\circ} \mathrm{C}$ and contact time of $299.93 \mathrm{~min}$ to get minimum SG and maximum $\mathrm{WL}$ and $\mathrm{WL} / \mathrm{SG}$ ratio. At these optimum points, $\mathrm{WL}, \mathrm{SG}$ and $\mathrm{WL} / \mathrm{SG}$ ratio were found to be $18.66 \%$, $5.78 \%$ and 2.73 , respectively. The predicted results were experimentally validated which were closely in agreement with experimental values. Therefore, optimum processing conditions obtained in this study may be recommended for osmotic dehydration of green chili.

\section{Acknowledgements}

We acknowledge the financial and logistic support given by the department of Food Engineering \& Technology, HSTU for the completion of the study.

\section{References}

[1] Ozdemir, M., Ozen, B. F., Dock, L. L., Floros, J. D. "Optimization of osmotic dehydration of diced green peppers by response surface methodology," LWT - Food Science and Technology, 41(10). 2044-50. Jan 2008.

[2] Isidoro, E., Cotter, D. J., Fernandez, G. C. J., Southward, G. M "Color retention in red chile powder as related to delayed harvest," Journal of Food Science, 60(5). 1075-7. Jan 1995.

[3] Tunde-Akintunde, T. Y., Afolabi, T. J., Akintunde, B. O. "Influence of drying methods on drying of bell-pepper (Capsicum annuum)," Journal of Food Engineering, 68(4).439-42. Jun 2005.

[4] Famurewa, J. A. V., Oluwamukomi, M. O., Adenuga, L. A., "Dehydration of osmosised red bell pepper (Capsicum annum)," Journal of food Technolology, 4(4). 249-52. 2006.

[5] Grabowski, S., Marcotte, M., Ramaswamy, H. S., Handbook of Postharvest Technology: Cereals, Fruits, Vegetables, Tea, and Spices, Marcel Dekker, New York, 2003, 653-695.

[6] Mandala, I. G., Anagnostaras, E. F., Oikonomou, C. K., "Influence of osmotic dehydration conditions on apple air-drying kinetics and their quality characteristics," Journal of Food Engineering, 69(3). 307-16. Aug 2005.

[7] Amami, E., Khezami, L., Vorobiev, E., Kechaou, N., "Effect of Pulsed Electric Field and Osmotic Dehydration Pretreatment on the Convective Drying of Carrot Tissue," Drying Technology, 26(2). 231-8. Feb 2008.

[8] Arslan, D., Özcan, M. M., "Dehydration of red bell-pepper (Capsicum annuum L.): Change in drying behavior, colour and antioxidant content," Food and Bioproduct Processing, 89(4). 504-13. Oct 2011.

[9] Raoult-Wack, A. L., "Recent advances in the osmotic dehydration of foods," Trends in Food Science and Technology, 5(8). 255-60. Aug 1994.

[10] Shi, J., Le Maguer, M., "Osmotic dehydration of foods: Mass transfer and modeling aspects," Food Reviews International, 18(4) 305-35. Feb 2002

[11] Chandra, S., Kumari, D., "Recent development in osmotic dehydration of fruit and vegetables: a review," Critical Reviews in Food Science and Nutrition, 55(4). 552-61. Sep 2013.

[12] Corrêa, J. L. G., Pereira, L. M., Vieira, G. S., Hubinger, M. D., "Mass transfer kinetics of pulsed vacuum osmotic dehydration of guavas," Journal of Food Engineering, 96(4). 498-504. Feb 2010.

[13] Yadav, B. S., Yadav, R. B., Jatain, M., "Optimization of osmotic dehydration conditions of peach," Journal of Food Science and Technology, 49(5). 547-55. Sep 2012.

[14] Phisut, N., "Minireview- Factors affecting mass transfer during osmotic dehydration of fruits," International Food Research Journal, 19(1). 7-18. 2012.

[15] Di Scala, K., Crapiste, G., "Drying kinetics and quality changes during drying of red pepper," LWT - Food Science and Technology, 41(5).789-95. Jun 2008.

[16] Myers, R. H., Montgomery, D. C., Response Surface Methodology Process and Product in Optimization Using Designed Experiments ( $1^{\text {st }}$ edition) John Wiley and Sons Inc., New York, 1995.

[17] AOAC, Official methods of Analysis, 15th edu. Association of Official Analytical chemist. Washington, DC, 2000.

[18] Bchir, B., Besbes, S., Karoui, R., Paquot, M., Attia, H., Blecker, C., "Osmotic Dehydration Kinetics of Pomegranate Seeds Using Date Juice as an Immersion Solution Base," Food and Bioprocess Technology, 5(3). 999-1009. Apr 2012

[19] Bolin, H. R., Huxsoll, C. C., Jackson, R., NG, K. C., "Effect of Osmotic Agents and Concentration on Fruit Quality," Journal of Food Science, 48(1). 202-5. Jan 1983.

[20] Ozen, B. F., Dock, L. L., Ozdemir, M., Floros, J. D., "Processing factors affecting the osmotic dehydration of diced green peppers," International Journal of Food Science and Technolology, 37(5). 497-502. Jun 2002.

[21] Mavroudis, N. E., Gekas, V., Sjöholm, I., "Osmotic dehydration of apples -effects of agitation and raw material characteristics," Journal of Food Engineering, 35(2). 191-209. Feb 1998.

[22] Panagiotou, N. M., Karathanos, V. T., Maroulis, Z. B., "Effect of osmotic agent on osmotic dehydration of fruits," Drying Technology, 17(1-2). 175-89. 1999.

[23] Eren, İ., Kaymak-Ertekin, F., "Optimization of osmotic dehydration of potato using response surface methodology," Journal of Food Engineering, 79(1). 344-52. Mar 2007. 
[24] Maran, J. P., Manikandan, S., Thirugnanasambandham, K., Nivetha, C.V., Dinesh, R., "Box-Behnken design based statistical modeling for ultrasound-assisted extraction of corn silk polysaccharide. Carbohydrate Polymer, 92(1): 604-11. Jan 2013.

[25] Mundada, M., Singh, B., Maske, S., "Optimisation of processing variables affecting the osmotic dehydration of pomegranate arils," International Journal of Food Science Technolology, 45(8) 1732-8. Jul 2010.

[26] Jain, S. K., Verma, R. C., Murdia, L. K., Jain, H. K., Sharma, G. P., "Optimization of process parameters for osmotic dehydration of papaya cubes," Journal of Food Science Technolology, 48(2). 211-7. Mar-Apr 2011.

[27] Azoubel, P. M., Murr, F. E. X, "Mass transfer kinetics of osmotic dehydration of cherry tomato," Journal of Food Engineering 61(3). 291-5. Feb 2004

[28] Uddin, M. B., Ainsworth, P., İbanoğlu, S., "Evaluation of mass exchange during osmotic dehydration of carrots using response surface methodology," Journal of Food Engineering, 65(4). 473-7. Dec 2004.

[29] Vieira, G. S., Pereira, L. M., Hubinger, M. D., "Optimisation of osmotic dehydration process of guavas by response surface methodology and desirability function," International Journal of Food Science and Technology, 47(1):132-40. Oct 2012.

[30] Lazarides, H. N., Katsanidis, E., Nickolaidis, A., "Mass transfer kinetics during osmotic preconcentration aiming at minimal solid uptake," Journal of Food Engineering, 25(2). 151-66. 1995.

[31] Ganjloo, A., Rahman, R. A., Bakar, J., Osman, A., Bimakr, M., "Optimization of osmotic dehydration of seedless guava (Psidium guajava L.) in sucrose solution using response surface methodology," International Journal of Food Engineering, 10(2). 307-16. Nov 2014.

[32] Jokić, A., Gyura, J., Lević, L., Zavargó, Z., "Osmotic dehydration of sugar beet in combined aqueous solutions of sucrose and sodium chloride," Journal of Food Engineering, 78(1): 47-51. 2007.

[33] Khoyi, M. R., Hesari, J., Osmotic dehydration kinetics of apricot using sucrose solution. Journal of Food Engineering, 78(4). 1355-60. 2007.

[34] İspir, A., Toğrul, İ. T., Osmotic dehydration of apricot: Kinetics and the effect of process parameters. Chemical Engineering Research and Design, 87(2). 166-80. Feb 2009.

(C) The Author(s) 2019. This article is an open access article distributed under the terms and conditions of the Creative Commons Attribution (CC BY) license (http://creativecommons.org/licenses/by/4.0/). 